\title{
SENSE OF PLACE PADA DESTINASI WISATA URBAN: KASUS TITIK NOL KILOMETER, YOGYAKARTA
}

\author{
SENSE OF PLACE IN URBAN TOURISM: \\ DESTINATION THE CASE OF TITIK NOL KILOMETER, YOGYAKARTA
}

\author{
${ }^{* 1}$ Bonifasia Yuniar Rifani \\ ${ }^{1}$ Program Studi Magister Kajian Pariwisata \\ Sekolah Pascasarjana Universitas Gadjah Mada, Yogyakarta \\ Submitted: 26-08-2020; Revised: 03-05-2021; Accepted:01-07-2021
}

\begin{abstract}
Urban tourism phenomenon has rarely been studied using both tourism and urban studies approach, whereas urban environment play an essential role in tourism attractiveness. This research investigates the considerably high tourist visit in public space of Titik Nol Kilometer Yogyakarta as an urban tourism phonemenon using a multidimensional concept of sense of place which explains relationship between the tourist (people) and the public area (place). The analysis is focused on the place making components that creates sense of place. The sense of place concept is explored through qualitative analysis, with data collected from physical and behavioural mapping, and online interviews with tourists. Overlay and interactive analytical model is performed to identify the sense of place and its component. Sense of place in Titik Nol Kilometer is identified as emotional relationship between tourist and public space setting which becomes not only a place for recreational or creative events performed by the citizen or local people, but also an attractive destination for tourist that brings personal experience of the unique life of Yogyakarta city. Sense of place is created by the connectedness of various elements based on physical setting, activity, and meaning parameters which coherently combined and complement each other's existence. The process involved the collaboration of planned place making and organic placemaking, which enable the coexistence of 'old and new', and 'local and tourist' contrast.
\end{abstract}

Keywords: Sense of Place; Place Making; Urban Tourism.

\begin{abstract}
ABSTRAK
Wisata urban merupakan topik yang belum banyak dikaji dari gabungan sudut pandang studi perkotaan dan pariwisata. Padahal, lingkungan urban menjadi daya tarik yang kuat bagi wisatawan, bahkan melebihi objek daya tarik wisata. Penelitian ini bertujuan mengkaji fenomena tingginya kunjungan wisatawan pada ruang publik Kawasan Titik Nol Kilometer Yogyakarta dengan menggunakan pendekatan sense of place, yakni menjelaskan hubungan antara destinasi wisata (place) dengan wisatawan (people). Analisis dilakukan untuk mengetahui bagaimana sense of place tercipta berdasarkan konsep place making. Metode yang digunakan dalam penelitian ini adalah kualitatif deskriptif, dengan pengumpulan data melalui pemetaan kawasan, place centered mapping, dan wawancara secara daring terhadap wisatawan. Data diolah menggunakan teknik overlay dan analisis interaktif. Penelitian ini menyimpulkan sense of place Kawasan Wisata Titik Nol Kilometer sebagai relasi emosional antara
\end{abstract}

${ }^{*}$ Corresponding author: bonifasiayr@gmail.com.

Copyright@ 2021 THE AUTHOR (S). This article is distributed under a Creative Commons Attribution-Share Alike

4.0 International license. Jurnal Kawistara is published by the Graduate School of Universitas Gadjah Mada. 
wisatawan dengan setting ruang publik yang tidak hanya menjadi ajang kreativitas dan rekreasi masyarakat lokal, namun juga menjadi daya tarik bagi wisatawan yang memungkinkan mereka menemukan pengalaman personal khas pada suasana kehidupan Kota Yogyakarta. Sense of place tercipta dari adanya keterhubungan antar beragam elemen berdasarkan parameter setting fisik, aktivitas, dan makna yang berpadu dalam satu tempat dengan tanpa mengganggu keberadaan satu sama lain, namun justru saling mengisi. Sense of place tercipta dengan melibatkan placemaking yang terencana, bersinergi dengan place-making yang berkembang secara organik.

Kata Kunci: Sense of Place; Place Making; Wisata Urban.

\section{PENGANTAR}

Wisata urban merupakan topikyang belum banyak dikaji secara mendalam dari dua sudut pandang bidang studi, yakni kajian pariwisata dan perkotaan. Padahal, lingkungan urban menjadi daya tarik yang kuat bagi wisatawan, bahkan melebihi objek daya tarik wisata (Boivin dan Tanguay, 2019). Besarnya kunjungan wisatawan di ruang publik perkotaan ini juga terjadi di Yogyakarta, yakni di Kawasan Wisata Titik Nol Kilometer. Meskipun tidak terdapat atraksi yang diciptakan secara khusus, tempat ini tidak pernah sepi oleh wisatawan. Tingginya kunjungan wisatawan ini menjadi fenomena yang diteliti dalam penelitian ini dengan menggunakan pendekatan place. Place yang dimaksud bukan merupakan sebuah lokasi geografis di mana wisatawan berkunjung, melainkan kualitas dari tempat itu sendiri (Smith, 2015). Konsep sense of place digunakan untuk mengkaji fenomena tersebut, yakni hubungan antara destinasi wisata urban sebagai place, dengan wisatawan sebagai manusia penggunanya.

Sense of place adalah konsep yang berkembang di berbagai bidang keilmuan seperti geografi, psikologi lingkungan, arsitektur, dan perencanaan. Konsep ini berangkat dari istilah-istilah yang telah ada lebih dulu yakni 'genius loci', 'topophilia' (Tuan, 1974), dan 'spirit of place' (Jackson, 1994). Ketiganya menggambarkan hubungan yang kuat dan positif antara tempat (place) dengan manusia (people). Tempat yang tidak memiliki sense of place kemudian disebut dengan istilah 'placelessness' (Relph, 1976). Manusia merespon sebuah setting melalui sistem indera (Shamai, 1991) dan memiliki persepsi sebagai proses memahami stimuli tersebut, terdiri dari dimensi kognitif, afektif, interpretatif, dan evaluatif (Carmona, et al, 2003). Sense of place merupakan pengalaman yang dirasakan manusia pada sebuah setting, berdasarkan interpretasi dan perasaan emosional, yakni perasaan terstimulasi, bersemangat, senang, dan gembira (Steele, 1981; Hummon 1992). Sense of place tidak diciptakan oleh suatu entitas yang tunggal, melainkan diciptakan secara multidimensional (Beidler dan Morrison, 2016; Najafi dan Shariff, 2011).

Salah satu konsep yang menjelaskan mengenai penciptaan sense of place adalah place making. Place making merupakan sebuah proses untuk menciptakan tempat yang berkualitas dan menarik, membuat orang ingin datang berkunjung, tinggal, dan bisa melakukan berbagai macam aktivitas di dalamnya (Wyckoff, 2014; PPS, 2017). Wyckoff (2014) menjelaskan makna dari berkualitas sebagai tempat yang aktif, unik, menarik secara visual, dan seringkali digunakan untuk aktivitas seni kreatif. Sebuah tempat yang berkualitas akan menciptakan sense of place yang kuat. Pada destinasi wisata, place making dapat menciptakan sense of place, citra, identitas, dan autentisitas dari sebuah tempat untuk menarik wisatawan (Razali dan Ismail, 2014; Zakariya, 2007). Place making juga mendorong terjadinya kunjungan berulang wisatawan melalui strategi penciptaan identitas sehingga sebuah destinasi memiliki citra kuat, yang juga berpengaruh terhadap kualitas pelayanan dan nilai-nilai yang di bawa (Habibah, et al, 2013; Razali dan Ismail, 2014).

Carmona, et al (2003) menyimpulkan place making menciptakan sense of place berdasarkan teori Punter dan Montgomery (1998); terdiri dari elemen setting fisik, aktivitas, dan makna. Teori tersebut dikembangkan dalam konteks perencanaan kota, yang kemudian disesuaikan oleh penelitian ini dalam konteks destinasi wisata urban. Setting fisik adalah benda 
fisik/terbangun atau built-form; aktivitas adalah kegiatan manusia yang terjadi; makna adalah persepsi termasuk penilaian dan karakteristik signifikan wisatawan. Konsep place making sendiri juga dapat ditinjau dari proses terjadinya, yakni 'placemaking' yang direncanakan dan 'place-making' yang terjadi secara organik (Lew, 2017). Peran kedua jenis place making tersebut dikaji dalam penelitian ini.

Dalam ranah pariwisata, sense of place telah dikaji oleh penelitian terdahulu. Temuan penting di antaranya menyebutkan bahwa sense of place memiliki pengaruh positif terhadap kepuasan dan kunjungan ulang wisatawan, termasuk loyalitas destinasi (Hwang, et al, 2005; Yuksel, et al, 2010; Abou-Shouk, 2017). Penelitian lain juga mengkaji faktor-faktor yang mempengaruhi sense of place dalam ranah pariwisata (Kyle, et al 2004; Gross dan Brown, 2008; Fan dan Qiu, 2014; Ramkissoon dan Mavondo, 2015), dan juga peran sense of place sebagai mediator (Prayag dan Ryan, 2011; Lee, et al, 2012; Smith, 2015). Penelitian-penelitian sebelumnya banyak mengkaji peran sense of place, namun belum berfokus pada kajian mengenai bagaimana sense of place tersebut tercipta.

Oleh karena itu, penelitian ini bertujuan untuk mengidentifikasi sense of place destinasi wisata urban dengan kasus Kawasan Titik Nol Kilometer Yogyakarta, dan bagaimana sense of place tercipta melalui place making yang dibahas berdasarkan parameter-parameter setting fisik, aktivitas, dan makna. Penelitian ini dapat memberikan manfaat berupa wawasan bagi dasar perencanaan pariwisata terutama dalam konteks wisata urban agar dapat merancang tempat dengan sense of place yang kuat sehingga mampu memberikan pengalaman berkualitas bagi wisatawan, sekaligus mendukung keberlanjutan destinasi wisata.

Pendekatan yang digunakan dalam penelitian ini adalah kualitatif deskriptif. Pengumpulan data dilakukan dengan tiga teknik, yakni pemetaan fisik kawasan, pemetaan aktivitas pengunjung menggunakan place centered mapping, dan wawancara terhadap wisatawan secara daring (menyesuaikan kondisi pandemi SARS-COV-2). Pemetaan fisik kawasan meliputi ruang dan bangunan; aksesibililitas dan sirkulasi; dan street furniture (tempat duduk, vegetasi, penerangan, bollards, tempat sampah, signage, tempat sepeda, monumen, instalasi seni, dan fasilitas penyandang disabilitas). Place centered mapping dilakukan untuk mengetahui aktivitas yang terjadi di kawasan. Pemetaan ini dilakukan pada hari biasa, Hari Sabtu, dan Hari Minggu pada pagi (08.00-10.00), siang (12.00-14.00), sore (16.00-18.00), dan malam hari (19.0021.00). Wawancara secara daring dilakukan untuk mengetahui makna kawasan menurut wisatawan. Wawancara dilakukan terhadap 17 informan wisatawan yang pernah berkunjung ke Kawasan Titik Nol Kilometer Yogyakarta dalam kurun waktu tiga tahun terakhir. Data juga dilengkapi dari ulasan pengunjung pada mesin pencari Google dengan mencari kata kunci yang relevan.

Metode analisis yang digunakan adalah analisis overlay dan analisis interaktif. Analisis overlay digunakan untk menggabungkan data setting fisik dengan data aktivitas berupa place centered mapping guna mengetahui intensitas, jenis, sebaran, dan pola aktivitas pengunjung. Analisis interaktif digunakan untuk menganalisis hasil wawancara dan ulasan guna mengetahui makna kawasan menurut wisatawan. Analisis ini juga digunakan untuk melakukan kajian akhir yakni keterkaitan antara hasil analisis pertama dan kedua hingga didapatkan jawaban mengenai bagaimana sense of place tercipta, dan mengidentifikasi sense of place tersebut. Lokasi penelitian ini adalah Kawasan Wisata Titik Nol Kilometer yang terletak di pusat Kota Yogyakarta. Tempat ini merupakan ruang publik di kawasan bersejarah yang banyak dikunjungi oleh wisatawan.

\section{PEMBAHASAN Setting Fisik Kawasan}

Titik Nol Kilometer adalah kawasan pertemuan dari empat ruas jalan utama di pusat Kota Yogyakarta. Kawasan ini berada dekat dengan beberapa destinasi wisata utama seperti Kawasan Kraton dan Malioboro. Lokasi strategis kawasan ini memiliki aksesibilitas yang baik. Secara setting fisik, kawasan ini 
dibentuk oleh placemaking yang direncanakan, yakni placemaking di masa lampau dan saat ini. Placemaking masa lampau ditunjukkan oleh dominasi oleh bangunan-bangunan penting yang dibangun pada masa Pemerintahan Hindia Belanda. Bangunan berarsitektur kolonial tersebut kini menjadi bangunan cagar budaya yang masih dilestarikan. Sebagian bangunan masih memiliki fungsi yang sama sejak pertama kali dibangun, sebagian lain telah berubah. Meskipun sebagian besar bangunan bersejarah di kawasan ini bukan merupakan objek daya tarik wisata, wisatawan menikmati keberadaannya secara visual. Bangunan bersejarah ini dilestarikan dengan baik sehingga masih menonjolkan arsitektur aslinya dan didukung dengan pencahayaan di malam hari. Wisatawan menikmati keberadaan bangunan ini untuk menikmati suasana masa lampau maupun untuk berfoto.

Placemaking masa kini diwujudkan dalam bentuk penataan ruang publik berupa jalur pedestrian yang dilengkapi dengan street furniture. Bagian dari street furniture yang banyak digunakan oleh pengunjung adalah bangku dan bollards. Meskipun memiliki fungsi awal sebagai pembatas dengan jalan raya, bollards seringkali banyak dipilih sebagai tempat untuk duduk bersantai walaupun letaknya berdekatan dengan lalu lintas. Beberapa street furniture menjadi daya tarik tersendiri bagi wisatawan seperti signage penunjuk arah, instalasi seni Bedjokarto, dan Monumen Batik yang sering dijadikan sebagai objek berfoto. Street furniture lain yang memiliki fungsi primer di kawasan ini adalah vegetasi, tempat sampah, tempat parkir sepeda, dan fasilitas bagi penyandang disabilitas. Kawasan ini juga merupakan jalur pedestrian dengan area yang cukup luas sehingga memungkinkan wisatawan untuk singgah dan melakukan berbagai macam aktivitas. Secara aksesibilitas, lokasi kawasan juga terletak di pusat kota sehingga mudah diakses, dan berada dekat dengan destinasi wisata lainnya terutama Kraton Yogyakarta dan Malioboro yang dapat dijangkau dengan berjalan kaki.

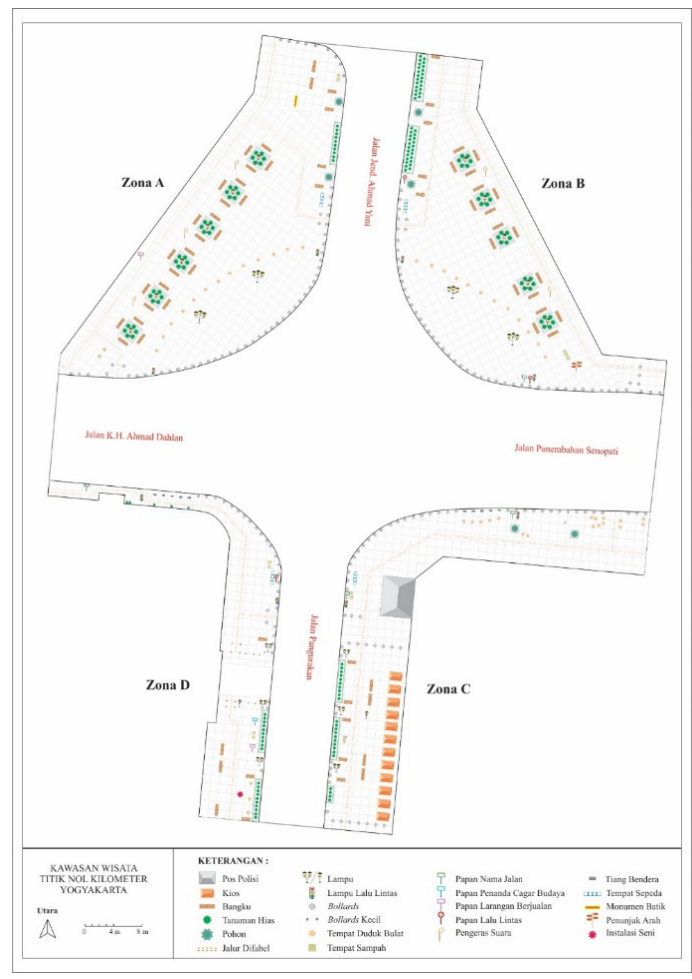

Gambar 1.

Peta Setting Fisik Kawasan Sumber: Survey lapangan, 2020.

\section{Aktivitas Kawasan}

Kawasan Wisata Titik Nol Kilometer digunakan untuk berbagai macam aktivitas baik oleh warga kota maupun wisatawan. Hasil pemetaan menunjukkan kawasan ini paling ramai dikunjungi pada Hari Sabtu dan Minggu saat sore dan malam hari. Sebagian informan menyebutkan waktu terbaik untuk berkunjung adalah pada saat senja hari, dan sebagian lainnya menikmati waktu saat larut malam. Rata-rata wisatawan menghabiskan waktu selama 1 jam di tempat ini. Beberapa informan juga mneyebutkan dapat menghabiskan waktu selama lebih dari 2 jam. Bagian kawasan dengan tingkat kunjungan paling tinggi adalah bagian utara kawasan yang memiliki area paling luas dan berbatasan dengan ruang terbuka. Di bagian ini, wisatawan juga dapat memandang bangunan-bangunan bersejarah secara keseluruhan.

Hasil dari pemetaan aktivitas di Kawasan Wisata Titik Nol Kilometer menunjukkan adanya aktivitas yang beragam, di antaranya pengunjung berjalan kaki; bersepeda; duduk untuk beristirahat atau bersantai; berinteraksi 
dengan rekan perjalanan maupun dengan pengunjung lain; berfoto dengan latar belakang bangunan bersejarah, signage, instalasi seni, dan Monumen Batik; jual beli makanan/minuman/ lainnya; kegiatan komunitas; dan pertunjukan.

Terkait dengan aktivitas wisata, sebagian besar wisatawan mengunjungi kawasan ini untuk duduk bersantai, berbincang, dan berfoto. Wisatawan menikmati singgah di tempat ini juga untuk mengamati aktivitas pengujung lain dan memotret momen yang ada, termasuk aktivitas warga kota. Sebagian wisatawan melakukan interaksi dengan komunitas yang berkumpul di tempat ini, seperti sepeda onthel, pegiat literasi dan mainan tradisional, seni dan sastra. Beberapa kegiatan mereka memunculkan keterlibatan dengan wisatawan mulai dari saling bertukar wawasan hingga mengisi acara dalam pertunjukan yang diselenggarakan. Pertunjukan juga menjadi aktivitas temporal yang dinikmati wisatawan, termasuk pertunjukan oleh musisi jalanan. Beragam aktivitas ini merupakan bagian dari place-making yang terjadi secara organik dan menghidupkan kawasan.

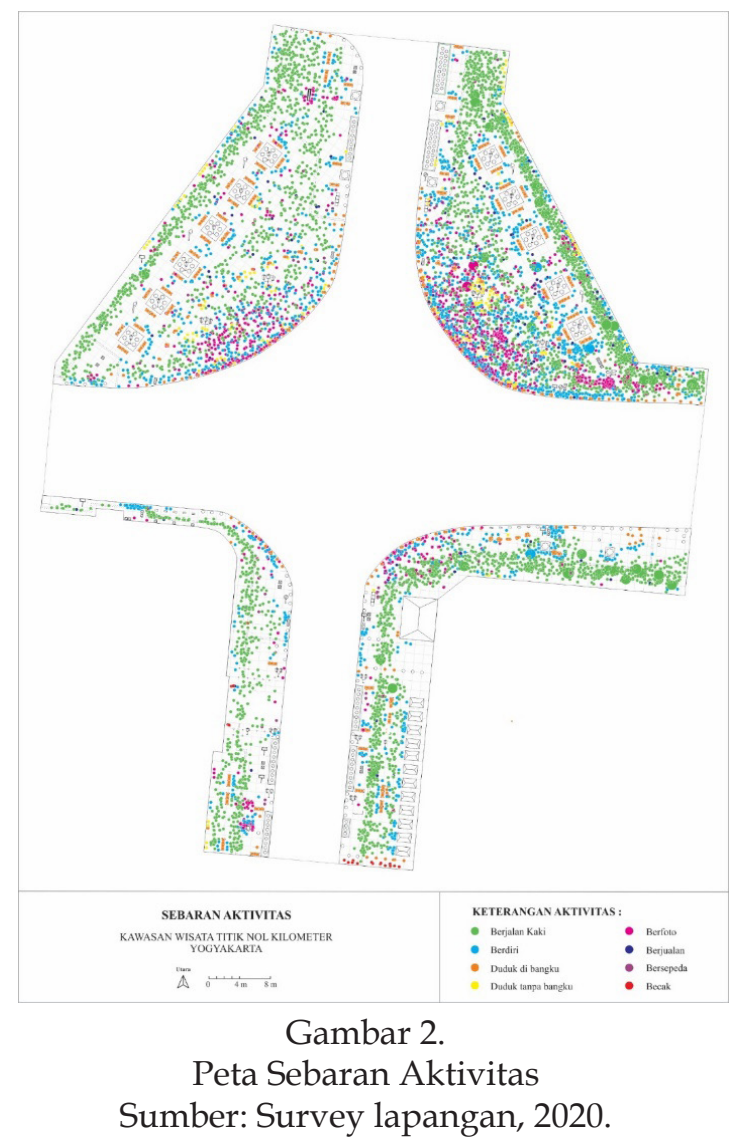

\section{Makna Kawasan}

Makna Kawasan Wisata Titik Nol Kilometer Yogyakarta digali dari persepsi wisatawan dan keterikatan wisatawan terhadap kawasan yang didapatkan dari hasil wawancara terhadap informan. Wisatawan memiliki persepsi yang beragam mengenai kawasan ini, dengan kecenderungan sense of place atau hubungan antara tempat dan manusia yang bernilai positif.

Ketujuh belas informan menilai kawasan ini sebagai tempat yang ikonik, unik, dan istimewa. Salah satu di antaranya berpendapat bahwa meskipun kota-kota lain di Indonesia memiliki kawasan dengan bangunan cagar budaya yang serupa, namun suasana di kawasan ini berbeda. Keistimewaan ini dianggap tidak hanya secara visual karena keberadaan bangunan berasitektur khas kolonial dan desain street furniture yang khas, namun juga aktivitas pengunjung di dalamnya dan untuk menjadi bagian dari keramaian dalam menikmati kawasan tersebut. Keunikan juga dinilai dari adanya aktivitas di ruang publik yang dianggap tidak biasa seperti pertunjukan kecil musisi jalanan, pantomim, dan instalasi seni.

Secara fisik, kawasan ini menjadi tempat favorit untuk berfoto bagi sebagian informan. Salah seorang informan menyebutkan bahwa ciri khas tempat ini begitu kuat sehingga siapapun yang berfoto di sana akan mengenali lokasinya. Sebagian informan lain menekankan bahwa kawasan ini adalah tempat yang menarik untuk memotret berbagai momen, terutama aktivitas yang dilakukan oleh warga kota dalam latar Kota Yogyakarta yang khas.

Sebagian besar informan juga menyebutkan kawasan ini sebagai tempat yang menyenangkan untuk bersantai atau nongkrong, berbincang, dan berdiskusi sehingga mereka bisa menghabiskan waktu cukup lama di sana. Banyak di antara mereka yang datang tanpa tujuan aktivitas tertentu, dan menghabiskan waktu untuk berbincang dengan rekan perjalanan maupun dengan pengunjung lain, salah satunya dengan pegiat komunitas yang juga berkumpul di kawasan ini. Hal ini juga membawa informan pada persepsi kawasan 
yang ramah, baik karena pertemuan mereka dengan warga kota maupun dengan wisatawan lain. Para informan juga menyebut kawasan ini sebagai tempat yang nyaman dengan keramaian yang justru dapat dinikmati. Para informan cenderung memiliki kenangan yang baik di tempat ini, sebagian menyebutnya sebagai pengalaman yang "memorable" atau mudah diingat. Mereka menyatakan adanya kerinduan atau keinginan untuk berkunjung kembali.

\section{Place Making: Menciptakan Sense of Place}

Sense of place dapat tercipta pada destinasi wisata urban berdasarkan karakteristik dan keterkaitan antar komponen place making. Pada komponen setting fisik, sense of place tercipta dari ruang publik di kawasan bersejarah pada lokasi strategis yang dilengkapi dengan fasilitas untuk pengunjung. Kawasan bersejarah direpresentasikan melalui bangunan-bangunan lama dengan arsitektural yang berbeda dengan bangunan pada umumya di kota ini. Sedangkan lokasi strategis diwujudkan dengan letak yang berada di pusat kota dan dekat dengan tempat wisata lainnya. Ruang publik ini didesain dengan penataan street furniture yang tidak hanya fungsional untuk memenuhi kebutuhan pengunjung namun juga dianggap menarik secara visual.

Pada aspek aktivitas, sense of place tercipta dari penggunaan tempat oleh pengunjung untuk melakukan berbagai macam aktivitas, termasuk warga kota sebagai pengguna utama ruang publik, maupun wisatawan sebagai pendatang. Aktivitas tersebut terdiri dari duduk bersantai menikmati suasana, berfoto, berinteraksi, terlibat secara aktif maupun pasif dalam kegiatan komunitas dan pertunjukan seni. Warga kota dan wisatawan saling berbagi ruang bahkan saling berinteraksi melalui beragam cara. Kawasan ini memungkinkan siapapun untuk berkunjung dan memanfaatkan tempat tanpa merasa saling terganggu. Justru, berbagai macam aktivitas yang dilakukan di dalamnya mejadikan tempat ini hidup, menjadi daya tarik, dan bisa dinikmati dengan nyaman.
Berdasarkan hasil analisis dari wawancara informan wisatawan, makna kawasan yang berperan dalam menciptakan sense of place destinasi wisata urban adalah menarik/ikonik, inklusif; sociable/ramah, relaxing/nyaman, dan vibrant/hidup. Makna menarik/ikonik berdasarkan pendapat informan wisatawan akan kawasan yang unik secara visual, adanya ragam aktivitas, dan tempat favorit untuk berfoto. Makna sociable/ramah berdasarkan persepsi mereka akan keterbukaan pengunjung untuk saling berinteraksi. Makna relaxing/ nyaman disebutkan secara langsung oleh informan mengenai pengalaman mereka singgah di kawasan ini dalam waktu yang cukup lama. Makna vibrant/hidup diperkuat dari pendapat mereka yang senang akan adanya berbagai pertunjukan informal dan bagaimana mereka menikmati keramaian suasana. Berdasarkan pendapat wisatawan, kelimanya merupakan karakteristik yang paling kuat dari destinasi wisata urban ini, dan menjadi identitas dari kawasan. Identitas yang dimiliki menjadikan kawasan istimewa, artinya tidak sama dengan destinasi lain. Kelima makna tersebut berpadu dan pada akhirnya mampu menonjolkan suasana khas dari salah satu ujud kehidupan Kota Yogyakarta yang memberi memori kuat bagi wisatawan akan kawasan yang dikunjunginya.

Ketiga komponen place making memiliki karakteristik yang saling berkaitan dan mendukung keberadaan satu sama lain. Ketiganya merupakan wujud dari placemaking yang direncanakan (setting fisik) dan placemaking yang terjadi secara organik (aktivitas dan makna). Eksistensi keduanya diperlukan guna menciptakan sense of place destinasi wisata urban. Placemaking yang direncanakan berperan penting dalam merevitalisasi kawasan dengan tetap memperhatikan kebutuhan pengunjung. Desain penataan ruangnya banyak diwujudkan dalam bentuk street furniture. Place-making terjadi karena kawasan yang telah didesain dapat dimanfaatkan oleh pengunjung yakni warga kota dan wisatawan. Kawasan ini memungkinkan keduanya untuk dapat saling berbagi ruang dan berinteraksi dengan nyaman di kawasan ini. Berbagai 


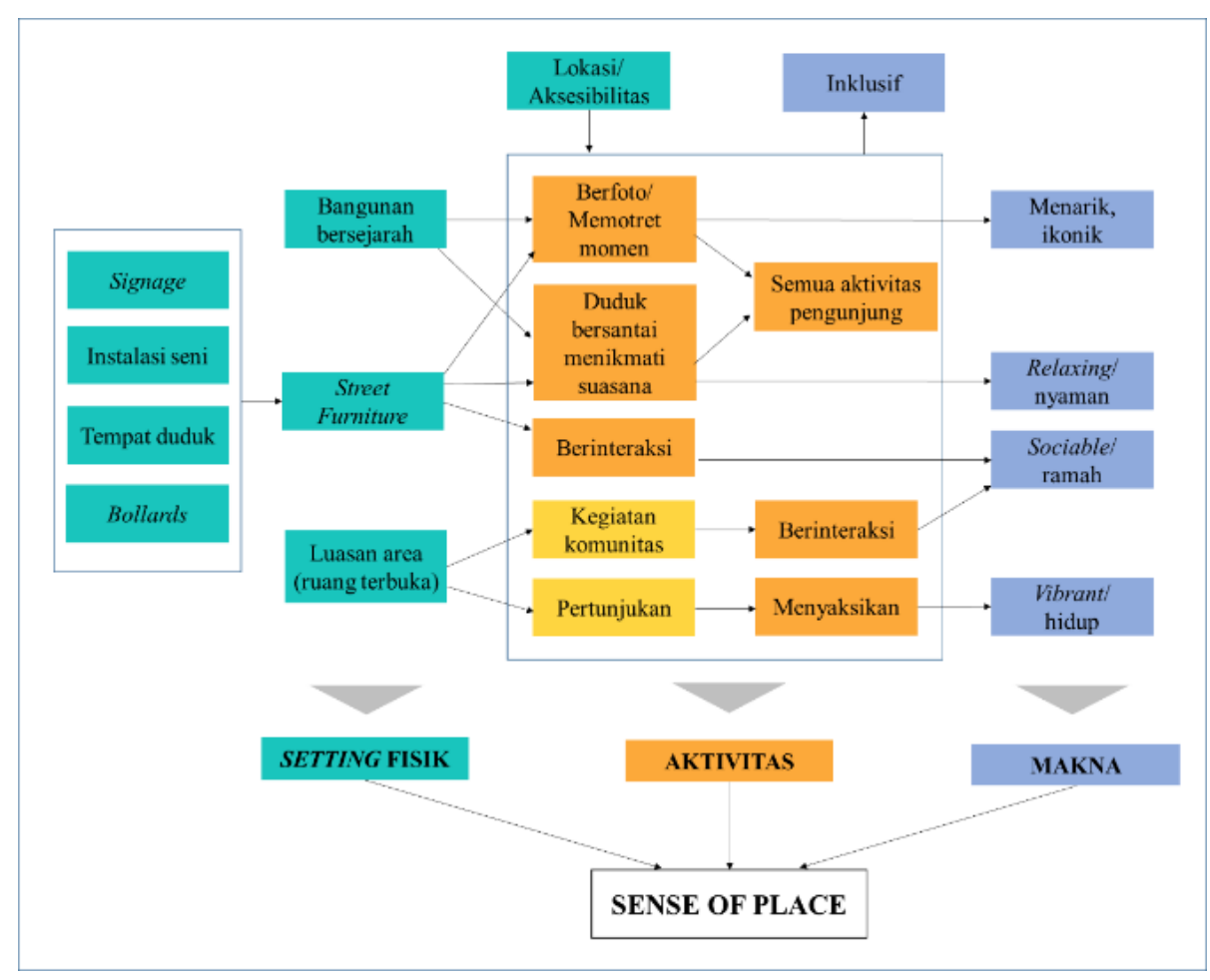

Gambar 3.

Keterkaitan Setting Fisik, Aktivitas, dan Makna Sumber: Analisis Peneliti, 2020.

macam aktivitas muncul secara organik oleh pengunjung sebagai pengguna kawasan sehingga dapat menghidupkan kawasan tersebut dan menandai adanya sense of place yang kuat. Tanpa placemaking yang tepat dan sesuai, place-making pun tidak dapat terjadi di tempat ini. Oleh karena itu, placemaking yang direncanakan dan place-making yang terjadi secara organik memiliki peran yang sama besarnya dalam menciptakan sense of place destinasi wisata urban. Keduanya saling mendukung keberadaan satu sama lain.

Sense of place Kawasan Wisata Titik Nol Kilometer yang tercipta melalui place making memenuhi atribut "What makes a great place" (Project for Public Space, 2007). Kawasan Wisata Titik Nol Kilometer memenuhi keempat atribut tersebut, yakni (1) Uses and activites diwujudkan oleh penggunaan kawasan oleh beragam pengunjung untuk melakukan berbagai macam aktivitas, baik individu maupun kolektif. (2) Sociability ditunjukkan dari adanya interaksi sosial yang kuat kawasan ini, yakni antar wisatawan, warga kota, maupun antara keduanya. (3) Accesibility and access kawasan ini tergolong baik karena dapat dijangkau dengan mudah, dan terkoneksi dengan daerah di sekitarnya. (4) Comfort and image dinilai berdasarkan kenyamanan wisatawan untuk berkunjung ke tempat ini, yang juga dinilai dengan citra positif. Terpenuhinya keempat atribut tersebut menunjukkan bahwa Kawasan Wisata Titik Nol Kilometer merupakan destinasi wisata urban dengan sense of place yang kuat.

Sense of place inilah yang menjadikan Kawasan Wisata Titik Nol Kilometer ramai dikunjungi oleh wisatawan, meski masih ada kecenderungan waktu kunjung yang berpuncak hanya pada sore dan malam hari. Secara umum, wisatawan memiliki penilaian yang positif mengenai kawasan ini dan menjadikan kawasan ini sebagai destinasi yang istimewa. Penilaian pengunjung terhadap kawasan ini termasuk tinggi, yakni mencapai 4,7 berdasarkan lebih dari 14.000 ulasan di mesin pencari Google. Hasil wawancara terhadap informan juga menunjukkan 
penilaian wisatawan yang positif terhadap kawasan, yakni melalui ungkapan perasaan senang, bahagia, kagum, dan gembira ketika berkunjung. Sense of place juga menjadikan wisatawan memiliki keterikatan berupa loyalitas destinasi. Seluruh informan juga mengungkapkan keinginan mereka untuk berkunjung kembali, meski sudah berulang kali mengunjungi tempat ini. Hal ini menunjukkan bahwa wisatawan memiliki keterikatan yang kuat terhadap kawasan ini. Oleh karena itu, sense of place menjadi konsep yang perlu dipertimbangkan dalam perencanaan destinasi wisata, khususnya dalam konteks wisata urban.

Sense of place Kawasan Wisata Titik Nol Kilometer di Yogyakarta dapat disimpulkan sebagai relasi emosional antara wisatawan dengan setting ruang publik yang sebenarnya tidakmenawarkan atraksi wisata secara spesifik, namun dapat merepresentasikan suasana yang kuat dari salah satu ujud kehidupan di Kota Yogyakarta bagi wisatawan. Tempat ini berkembang sedemikian rupa -secara historis hingga saat ini-sehingga dapat dikenali dengan mudah dari adanya setting kawasan yang autentik dan keramaian warga kota maupun wisatawan yang mengisinya dengan beragam aktivitas sehingga menghidupkan bagian dari pusat Kota Yogyakarta ini. Relasi ini berujung pada keterikatan yang muncul dalam bentuk memori tempat yang kuat bagi wisatawan, kerinduan untuk berkunjung kembali, dan diwujudkan dengan kunjungan berulang.

Sense of place Kawasan Wisata Titik Nol Kilometer di Yogyakarta tercipta dari adanya keterhubungan (connectedness) antar beragam elemen (berdasarkan parameter setting fisik, aktivitas, dan makna) yang berpadu dalam satu tempat dengan tanpa mengganggu keberadaan satu sama lain, namun justru saling mengisi. Keterhubungan tersebut terjadi secara 'bebas', informal, dan tidak terikat pada setting atau aturan tertentu. Keterhubungan ini menegaskan, bahwa sense of place tidak bisa diciptakan melalui elemen yang berdiri secara tunggal, melainkan saling terkait hingga menghasilkan perpaduan yang pas dari elemenelemen tersebut. Sense of place yang terbentuk diwujudkan oleh kunjungan yang tinggi dari waktu ke waktu baik oleh masyarakat setempat maupun wisatawan, dan sekaligus menunjukkan terjadinya keberlanjutan sebagai destinasi wisata urban.

Terdapat kutub-kutub yang kontras yang merupakan perpaduan yang mencolok di Kawasan Titik Nol Kilometer, yakni melibatkan kontras waktu (lampau dan kini) dan kontras asal (warga lokal dan wisatawan). Kontras waktu diwujudkan dalam bentuk bangunan masa Pemerintahan Hindia Belanda yang eksistensinya secara visual dan fungsional masih relevan hingga saat ini, dan keberadaan ruang publik yang menyesuaikan kebutuhan aktivitas kehidupan urban masa lalu dan masa kini. Keduanya terbangun selaras dalam satu kawasan, dan melebur dalam mewadahi pemanfaatan-pemanfaatan yang berkembang secara organik di dalamnya.

Kontras asal melibatkan warga kota sebagai pengisi ruang publik untuk kebutuhan rekreatif dan ekspresif dan wisatawan dari berbagai daerah yang menjelajahi dan mengenal kota melalui ruang-ruang populer. Sebagai ruang publik, Titik Nol Kilometer menjadi tempat pertemuan keduanya yang saling berbagi ruang, berinteraksi, dan terlibat secara pasif maupun aktif. Dibandingkan dengan objek wisata, kehidupan kota dapat dinikmati dengan jelas oleh wisatawan pada ruang publik yang kemudian juga berperan sebagai destinasi wisata urban. Dari situasi inilah muncul identitas yang dapat dikenali dengan mudah, yang merupakan representasi kehidupan Kota Yogyakarta.

\section{Diskusi Temuan}

Boivin dan Tanguay (2019) dalam penelitiannya menemukan peran lingkungan perkotaan sebagai daya tarik yang besar bagi wisatawan, bahkan melebihi atraksi objek daya tarik wisata. Dalam wisata urban, hal ini ditunjukkan dengan tingginya kunjungan wisatawan ke ruang-ruang publik perkotaan. Fenomena ini juga terjadi di Kota Yogyakarta, yakni di Kawasan Wisata Titik Nol Kilometer. Penelitian ini mengkaji fenomena tersebut berdasarkan konsep sense of place yang menjelaskan hubungan antara 
place dan manusia (Tuan, 1974; Steele, 1981; Shamai, 1991; Hummon, 1992; Williams, 1998). Penelitian ini menemukan bahwa dalam konteks wisata urban, sense of place merupakan hubungan antara destinasi, warga kota, dan wisatawan. Berbeda dengan objek daya tarik wisata yang pada umumnya hanya ditujukan bagi wisatawan, kawasan wisata pada ruang publik kota juga digunakan oleh warga kota. Warga kota dan wisatawan memanfaatkan tempat ini untuk melakukan berbagai macam aktivitas, baik secara terpisah maupun bersama. Menariknya, keduanya bisa saling berbagi ruang tanpa merasa terganggu dengan keberadaan satu sama lain, bahkan saling berinteraksi.

Secara umum, sense of place ditandai dengan besarnya kunjungan wisatawan di suatu kawasan. Sense of place juga tampak dari respon wisatawan berdasarkan pengalaman kunjungan mereka yakni perasaan senang, bahagia, gembira, dan antusias. Hal ini sejalan dengan pendapat Steele (1981) bahwa sense of place adalah pengalaman yang dirasakan seseorang pada sebuah setting, yakni perasaan terstimulasi, bersemangat, senang, dan gembira. Perasaan emosional terhadap tempat ini juga ditekankan oleh Hummon (1992). Selain itu, adanya sense of place dapat dilihat dari keterikatan wisatawan terhadap kawasan berupa loyalitas destinasi. Sama dengan penelitian-penelitian yang telah dilakukan sebelumnya, penelitian ini menemukan adanya kunjungan berulang dan keinginan untuk berkunjung kembali (Hwang, et al, 2005; Yuksel, et al, 2010; Abou-Shouk, 2017).

Sense of place diciptakan oleh place making yang terdiri dari tiga komponen yakni setting fisik, aktivitas, dan makna (Whyte, 1980; Punter dan Montgomerry, 1998; Jackson, 1994). Penelitian ini mengeskplorasi secara lebih rinci bagian-bagian dari komponen yang menciptakan sense of place destinasi wisata urban berdasarkan ketiga komponen tersebut. Hasil temuan menegaskan penelitian sebelumnya yang menyatakan bahwa sense of place tidak diciptakan oleh suatu entitas yang tunggal, melainkan multidimensional (Najafi dan Sharrif, 2011; Beidler dan Morrison, 2016).
Menggunakan konsep Lew (2007), penelitian ini menekankan pentingnya peran placemaking yang direncanakan dan place-making yang terjadi secara organik dalam proses terciptanya sense of place.

Selain itu, meski tidak mengkaji aspek sosial secara lebih mendalam, penelitian juga ini menggarisbawahi dimensi sense of place yang dijelaskan oleh Beidler dan Morrison (2016). Kehadiran masyarakat dan adanya aktivitas sosial menjadi pondasi dari identitas budaya suatu tempat dalam menciptakan sense of place. Hal ini terkait dengan dimensi interaksi sosial yang menggambarkan pentingnya aspek sosial dalam menentukan keterikatan seseorang terhadap sebuah tempat. Hal ini perlu dikaji lebih lanjut menggunakan sudut pandang bidang studi ilmu sosial terutama terkait dengan aktivitas warga kota di ruang publik.

Penelitian-penelitian sebelumnya telah memberikan wawasan mengenai pentingnya kajian sense of place. Di destinasi wisata, sense of place dapat memberi pengaruh terhadap persepsi wisatawan (Ram, et al, 2016), perilaku wisatawan (Cheng dan $\mathrm{Wu}, 2014$ ), kepuasan wisatawan dan loyalitas destinasi (Hwang, et al, 2005; Yuksel, et al, 2010; Abou-Shouk, et al, 2017). Temuan-temuan tersebut menunjukkan bahwa sense of place berperan dalam keberlanjutan destinasi wisata, baik sebagai faktor yang berpengaruh maupun mediator. Melalui pendekatan spasial, penelitian ini berkontribusi dengan menemukan bagaimana sense of place tercipta, khususnya dalam konteks destinasi wisata urban.

\section{Implikasi Penelitian}

Penelitian ini menunjukkan bahwa kawasan Titik Nol Kilometer memiliki sense of place yang relatif kuat yang dikaji berdasarkan informasi dari para wisatawan. Apabila dilihat secara lebih detail, sense of place tidak terjadi penuh secara merata, melainkan terjadi secara sporadis terutama pada bagian kawasan yang memiliki kelengkapan yang mempunyai karakteristik penciptaan sense of place. Selain itu, sense of place dirasakan terutama pada waktu yang terbatas, yakni pada sore dan malam hari. Oleh karena itu pengembangan 
setting fisik perlu diperkuat agar lebih berperan dalam merekayasa ruang yang dapat menjangkau tujuan penciptaan tempat (placemaking) sehingga dapat memenuhi harapanharapan yang berkaitan dengan aspek aktivitas maupun makna. Harapan-harapan tersebut meliputi jangkauan area yang lebih luas serta jangkauan waktu yang lebih lama. Sense of place juga memungkinkan untuk diperkuat dengan adanya konektivitas yang lebih baik antar bagian-bagian dalam kawasan. Konektivitas ini memungkinkan wisatawan melakukan eksplorasi tempat secara lebih luas tanpa adanya keterbatasan akses.

Penelitian ini masih menyisakan "ruang-ruang" yang perlu diisi dengan kajian sense of place menggunakan pendekatan ilmu lain seperti ilmu sosial dan psikologi. Penelitian selanjutnya juga dapat difokuskan pada keragaman profil wisatawan, yang mungkin dapat memunculkan penciptaan sense of place yang berbeda. Hal ini akan bermanfaat dalam merencanakan destinasi wisata urban dengan bagian-bagian yang dapat memenuhi kebutuhan segmen wisatawan yang berbeda.

Pada akhirnya, pengetahuan mengenai terciptanya sense of place diharapkan dapat melengkapi konsep sense of place dalam ranah ilmu pengetahuan dan praktik perencanaan destinasi wisata, khususnya (dalam kasus ini) destinasi wisata urban. Perencanaan wisata urban sebaiknya tidak hanya terfokus pada objek daya tarik wisata yang menjadi atraksi wisata utama di kota, namun juga menjangkau ruang-ruang publik yang mempunyai potensi sebagai daya tarik kuat bagi wisatawan. Selain itu, perlu adanya perencanaan yang menitikberatkan pada karakter lokal yang autentik (meskipun tidak harus dalam konteks sejarah maupun masa lalu), sekaligus dapat mewadahi kebutuhan pengunjung termasuk warga kota dan wisatawan.

\section{SIMPULAN}

Penelitian ini bertujuan untuk mengkaji fenomena tingginya kunjungan wisatawan di ruang publik Kawasan Wisata Titik Nol Kilometer Yogyakarta sebagai sebuah destinasi wisata urban. Menggunakan pendekatan hubungan antar tempat dan manusia, analisis dilakukan untuk mengetahui bagaimana sense of place tercipta melalui place-making. Data dikumpulkan melalui pemetaan fisik kawasan, place-centered mapping, dan wawancara mendalam terhadap informan wisatawan; serta dikaji dengan analisis overlay dan analisis interaktif.

Sense of place Kawasan Wisata Titik Nol Kilometer Yogyakarta secara umum ditunjukkan dengan tingginya kunjungan wisatawan, persepsi positif wisatawan terhadap kawasan, dan adanya keterikatan wisatawan. Lebih lanjut, penelitian ini menyimpulkan sense of place sebagai sebuah fenomena kawasan Titik Nol Kilometer di Yogyakarta yang tidak hanya dimanfaatkan sebagai ruang publik bagi masyarakat lokal dan sebagai ajang kreativitas, namun juga menjadi daya tarik bagi wisatawan yang memungkinkan mereka menemukan pengalaman personal yang khas pada suasana kehidupan Kota Yogyakarta. Para informan wisatawan menyebutkannya sebagai pengalaman yang tidak ditemukan di tempat lainnya. Identitas kawasan ini sangat mudah untuk dikenali sebagai representasi dari Kota Yogyakarta, memberi kenangan yang mudah untuk diingat, dan mendorong keinginan mereka untuk berkunjung kembali.

Hasil penelitian menunjukkan bahwa sense of place Kawasan Wisata Titik Nol Kilometer tercipta dari adanya keterhubungan (connectedness) dan perpaduan antar beragam elemen berdasarkan tiga parameter, yakni setting fisik, aktivitas, dan makna. Hubungan antar ketiganya diwujudkan dalam kolaborasi placemaking yang direncanakan dan placemaking organik. Placemaking diwujudkan dalam bentuk setting fisik perpaduan masa lampau dan masa kini, sedangkan place-making organik terwujud dalam ragam aktivitas dan makna yang dibentuk oleh warga kota maupun wisatawan. Hal ini juga menegaskan bahwa sense of place tidak diciptakan oleh entitas yang tunggal, melainkan multidimensional yang dalam penelitian ini dijelaskan melalui konsep place making. Pengetahuan mengenai bagaimana sense of place tercipta dapat memberikan kontribusi bagi keberlanjutan 
suatu destinasi wisata, khususnya destinasi wisata urban, sekaligus untuk memberikan pengalaman berkaulitas bagi wisatawan.

\section{DAFTAR PUSTAKA}

Abou-Shouk, M.A., Zoair, N., El-Barbary, M.N., and Hewedi, M.M. (2017). 'Sense of place relationship with tourist satisfaction and intentional revisit: Evidence form Egypt', International Journal of Tourism Research, pp 1-10. doi: 10.1002/jtr.2170.

Beidler, K. J. dan Morrison, J. M. (2016). ‘Sense of place: inquiry and application', Journal of Urbanism: Internationial Research on Placemaking and Urban Sustainability, 9(3) pp. 205-215. doi: 10.1080/17549175.2015.1056210.

Boivin, M. dan Tanguay, G. A. (2019). 'Analysis of the Determinants of Urban Tourism Attractiveness: The Case of Quebec City and Bordeaux', Journal of destination Marketing dan Management, 11 pp. 67 - 79. doi: 10.1016/j.jdmm.2018.11.002.

Carmona, M., Heath, T., Oc, T., dan Tiesdell, S. (2003). Public Places-Urban Spaces, The Dimension of Urban Design. Oxford: Architectural Press.

Cheng, T., dan Wu, H. (2015). 'How do environmental knowledge, environmental sensitivity, and place attachment affect environmentally responsible behavior? An integrated approach for sustainable island tourism', Journal of Sustainable Tourism, 23(4) pp. 557 - 576. doi: 10.1080/09669582.2014.965177.

Fan, J., Qiu, H. (2014). 'Examining the Effects of Tourist Resort Image on Place Attachment: A Case of Zhejiang, China', Public Personnel Management, 43(3) pp 340 - 354. doi: $10.1177 / 0091026014535180$.

Gross, M., dan Brown, G. (2008). 'An empirical structural model of tourists and places: Progressing involvement and place attachment into tourism', Tourism Management, 29(6) pp. 1141 - 1151. doi: 10.1016/j. tourman.2008.02.009.

Habibah, A., Idris M., Jusoh H., dan Er A. C. (2013). 'Place-Making of Ecotourism in Tasik Chini: From Exploratory to the Contemporary Biosphere Reserve', Asian Social Science, 9(6) pp 84 - 95. doi: 10.5539/ass.v9n6p84.

Hummon, D. M. (1992). Community Attachment: Local Sentiment dan Sense of Place. New York: Plenum.

Hwang, S., Lee, C., dan Chen, H. (2005). 'The relationship among tourists' involvement, place attachment and interpretation satisfaction in Taiwan's national parks', Tourism Management, 26(2) pp. 143 - 156. doi: 10.1016/j.tourman.2003.11.006.

Jackson, J.B. (1994). A Sense of Place, a Sense of Time. New Haven, CT: Yale University Press.

Kyle, G., Mowen, A., dan Tarrant, M. (2004). 'Linking place preferences with place meaning: An examination of the relationship between place motivation and place attachment', Journal of Environmental Psychology, 24(4) pp. 439 - 454. doi: 10.1016/j. jenvp.2004.11.001.

Lee, J., Kyle, G., dan Scott, D. (2012). 'The mediating effect of place attachment on the relationship between festival satisfaction and loyalty to the festival hosting destination', Journal of Travel Research, 51(6) pp. 754 - 767. doi: 10.1177/0047287512437859.

Lew, A. A. (2017) 'Tourism planning and place making: place-making or placemaking?', Tourism Geographies, 19(3) pp. 448-466. doi: 10.1080/14616688.2017.1282007.

Najafi M. dan Shariff, M. K. B. M. (2011). 'The Concept of Place and Sense of Place In Architectural Studies', International Journal of Humanities and 
Social Sciences, 5(8) pp. 1054-1060. doi: 10.5281/zenodo.1082223

Project for Public Spaces (PPS). (2007). The power of $10 \mathrm{C}$ : Applying placemaking at every scale. Diakses pada tanggal 28 September 2019 dari http://www.pps.org/ reference/ the-power-of-10/.

Prayag, G. dan Ryan, C. (2011). 'Antecedents of Tourists' Loyalty to Mauritius: The Role and Influence of Destination Image, Place Attachment, Personal Involvement, and Satisfaction', Journal of Travel Research, XX(X) $p p$. 1-15. doi: 10.1177/0047287511410321.

Ram, Y., Björk, P., dan Weidenfeld, A. (2016). 'Authenticity and place attachment of major visitor attractions', Tourism Management, 52 pp. 110 - 122. doi: 10.1016/j.tourman.2015.06.010.

Ramkissoonn, H. dan Mavondo, F. T. (2015). 'The Satisfaction-Place Attachment Realtionship: Potentials Mediators and Moderators', Journal of Business Research, pp. 10 - 19. doi: 10.1016/j. jbusres.2015.05.002.

Razali, M. K., dan Ismail, H. N. (2014). 'Tourism Place-Making at Tourism Destination from a Concept of Governance', International Journal of Ecology and Development, 30(3) pp. 8897.

Relph, E. (1976). Place and placelessness. London: Pion.

Shamai, S. (1991). 'Sense of Place: an Empirical Measurement', Geoforum, 22 pp. 347358. doi: 10.1016/0016-7185(91)90017$k$.
Smith, S. (2015). 'A Sense of Place: Place, Culture, and Tourism', Tourism Recreation Research, 40(2) pp. 220-233. doi: 10.1080/02508281.2015.1049814.

Steele, F. (1981). The sense of place. CBI Publishing Company, Inc.

Tuan, Y.F. (1974). Topophilia: A study of environmental perception, attitudes, and values. Englewood Cliffs, NJ: Prentice-Hall.

Wyckoff, M. (2014). Definitions of placemaking: Four different types. Planning dan Zoning News, 32(3). Diakses pada 10 Oktober 2019, dari http:/ / landpolicy.msu.edu/ news/article/lpis_mark_wyckoff_ authors_article_on_four_different_ types_of_placemaking.

Yuksel, A. (2001). 'Managing Customer Satisfaction and Retention: A Case of Tourist Destinations, Turkey', Journal of Vacation Marketing, 7(2) pp.153-168. doi: 10.1177/135676670100700205.

Yuksel, A., Yuksel, F., dan Bilim, Y. (2010). 'Destination attachment: Effects on customer satisfaction and cognitive, affective and conative loyalty', Tourism Management, 31(2) pp. 274 - 284. doi: 10.1016/j. tourman.2009.03.007.

Zakariya K., Mohyuddin M., dan Yaman M. (2007). 'Refining Tourist's Place Experience through Placemaking: Concepts and Correlations', International Journal of Diversity in Organisations, 6(4) pp. 249 - 258. doi: $\quad 10.18848 / 1447-9532 / C G P /$ v07i04/58018. 